\title{
Characterization of Trypanosoma cruzi
}

\author{
Silvane Maria Fonseca Murta/*, Alvaro José Romanha*/+ \\ Departamento de Bioquímica e Imunologia, ICB-UFMG, 30270-010 Belo Horizonte, MG, Brasil *Laboratório \\ de Parasitologia Celular e Molecular, Centro de Pesquisas René Rachou-Fiocruz, Av. Augusto de Lima 1715, \\ 30190-002, Belo Horizonte, MG, Brasil
}

Key words: Trypanosoma cruzi - genetic variation - populational heterogeneity

The Trypanosoma cruzi is a heterogeneous population, composed by a pool of strains which circulate in both the domestic and sylvatic life cycles including humans, vectors and animal reservoirs. Isolation and study of $T$. cruzi populations from different origins demonstrated the presence of a large range of strains with distinct biological, immunological, biochemical and pharmacological characteristics. Studies using cloned or uncloned T. cruzi populations, reinforce the heterogeneity of the parasite and demonstrate that the strains are composed of subpopulations with distinct characteristics (Postan et al. 1986, Finley \& Dvorak 1987).

Morphological differences in the T. cruzi blood forms have already been described by Chagas in 1909 in his classical paper on the discovery of Chagas disease (Chagas 1909). The role of the slender and broad bloodstream forms trypomastigotes were later thoroughly studied by Brener (1973). Nussenzweig et al. (1963) and Nussenzweig and Goble (1966) described immunological differences among $T$. cruzi strains. The strains were divided into three groups according to their cross-reaction with heterologous serum from infected mice. Following these biological and immunological observations, new approaches have been used for molecular characterization of $T$. cruzi.

Enzyme electrophoresis studies have demonstrated distinct $T$. cruzi populations (zymodemes) circulating in the domestic and sylvatic transmission cycles and provided a good epidemiological marker for Chagas disease. Miles et al. (1977, 1978) studying T. cruzi strains isolated from the Brazilian states of Bahia and Pará, described the

\footnotetext{
This work was supported by $\mathrm{CNPq}$, Papes-A/Fiocruz, Pronex no. 2704 and Fapemig.

${ }^{+}$Corresponding author. Fax: +55-031-295.3115. E-mail: romanha@netra.cpqrr.fiocruz.br

Received 9 June 1999

Accepted 9 August 1999
}

presence of three zymodemes (Z1, Z2 and Z3). Z1 and $\mathrm{Z} 3$ parasites were found in the sylvatic cycle and in a few human acute cases whereas Z2 parasites were found restricted in the domestic cycle of transmission. Romanha (1982) and Carneiro et al. (1990) characterizing T. cruzi samples isolated from chronic chagasic patients from, the endemic area of Bambuí, Minas Gerais, observed the presence of four distinct zymodemes (ZA, ZB, ZC and ZD). ZA was the same as Z2. ZB showed a characteristic heterozygous pattern generated by the hybridization between the parents ZA and ZC. Thus, in Brazil at least six major T. cruzi isoenzyme groups (Z1, Z2 or ZA, Z3, ZB, ZC and ZD) have been reported. Tibayrenc et al. (1986) and Tibayrenc and Ayala (1988), analyzing the isoenzymatic profiles (15 gene loci) of $645 \mathrm{~T}$. cruzi samples isolated from a variety of vertebrates and invertebrates hosts with a wide geographical distribution, observed a high genetic variability. They identified at least 43 distinct natural isoenzyme strains (zymodemes or "clonets"). Due to this high genetic variability and the findings of the same "clonets" geographically distant, the authors proposed a multiclonal population structure for $T$. cruzi and that its sexual reproduction was rare or absent (Tybayrenc \& Ayala 1988, Zhang et al. 1988).

Besides the isoenzymes, other molecular approaches have also pointed towards a high genetic variability in $T$. cruzi (reviewed by Macedo \& Pena 1998). The restriction fragment length polymorphism (RFLP) of the kinetoplast DNA (kDNA) minicircles demonstrated that almost every strain presents a different "schizodeme" (Morel et al. 1980). The heterogeneity was even higher when clones from the same strain were analyzed (Gonçalves et al. 1984). Improvements in the original protocol were made by Sturm et al. (1989) and Ávila et al. (1990). The variable segment of kDNA was amplified by the polymerase chain reaction (PCR) and its RFLP determined. Recently, the sequence variability of this fragment was studied directly in infected mice and chronic chagasic patients tissues, by LSSP-PCR (low-stringency single specific primer) (Vago et al. $1996 \mathrm{a}, \mathrm{b}$ ). The poly- 
morphism of the nuclear DNA (DNA fingerprinting) showed a good correlation with the schizodeme analysis (Macedo et al. 1992). Randomly amplified polymorphic DNA (RAPD) has also been used as an approach for the analysis of genetic variation and identification of genetic markers. Steindel et al. (1993) and Tibayrenc et al. (1993) observed a direct correlation between RAPD and isoenzyme profiles in T. cruzi. Recently, the PCR variant, SSR-PCR (single sequence repeat anchored primer PCR) was applied to study the genetic variability in $T$. cruzi (Oliveira et al. 1997). A hypervariable multiband profile was obtained with the DNA amplification of $T$. cruzi using the $(\mathrm{CA})_{8} \mathrm{RY}$ primer. The phylogenetic analysis of $T$. cruzi based on eight polymorphic loci of microsatellites $(\mathrm{CA})_{8}$ revealed a great genetic distance among the strains (Oliveira et al. 1998). Other nuclear markers as genes that code the ribosomal RNA 24S $\alpha$ and the mini-exon (Souto et al. 1996), spliced leader RNA and rRNA gene promoters (Nunes et al. 1997), have divided T. cruzi strains into two major phylogenetic lineages. An association of lineage 1 with domestic and lineage 2 with sylvatic cycle was observed (Zingales et al. 1998). Furthermore these genotypic markers showed a direct correlation with the phenotype characteristics previously determined by the isoenzymes. Restriction fragment length polymorphism of the rRNA gene 18S, allowed the classification of $T$. cruzi strains into three distinct groups, denominated "ribodemes" I, II and III (Clark \& Pung 1994). A correlation between the genetic markers of ribosomal RNA subunits $18 \mathrm{~S}$ and $24 \mathrm{~S}$ was observed.

The lack of condensed chromosomes during cell division, have prevented the T. cruzi characterization at the cytogenetic level. However, through pulse-field gel electrophoresis (PFGE) it was possible to verify that the $T$. cruzi genome is organized in approximately 20-25 chromosomal bands ranging from 0.3 to $1.6 \mathrm{Mb}$, usually with chromosomes larger than $1.6 \mathrm{Mb}$ accumulating in the compression region (Henriksson et al. 1990). The total and nuclear DNA contents have been reported to vary considerably among different $T$. cruzi strains and even between clones of the same strain (Dvorak et al. 1982, McDaniel \& Dvorak 1993). A correlation between karyotype pattern and isoenzyme classification has been proposed by Henriksson et al. (1993).

Previous studies on isoenzymes (Miles et al. 1977, Bogliolo et al. 1986, 1996, Tibayrenc et al. 1986), total DNA content (Borst et al. 1982), molecular karyotypes and restriction fragment length polymorphisms (Gibson \& Miles 1986, Aymerich \& Goldenberg 1986, Henriksson et al. 1990, Dietrich et al. 1990) and more recently microsatellites stud- ies (Oliveira et al. 1998) are in agreement with diploidy in T. cruzi and also support that the genome of this parasite is remarkably plastic. Despite the genetic diversity and diploidy of $T$. cruzi, it has been proposed that this parasite has a clonal population structure and asexual reproduction, this is supported by the great deviation from Hardy-Weinberg equilibrium observed in natural populations (Tibayrenc et al. 1990). Nevertheless, izoenzyme analysis and RFLP of three glycolytic genes demonstrated the presence of the heterozygotes and the corresponding homozygotes circulating in the same area (Bogliolo et al. 1996). These findings support the hypothesis of genetic exchange in T. cruzi. In agreement with these results, Carrasco et al. (1996) analyzing isoenzyme and RAPD profiles of T. cruzi strains from Central and South America, suggested that genetic exchange occurs during sylvatic transmission of T. cruzi, and that it contributes to the generation of phenotypic and genotypic diversity in this parasite.

The correlation between $T$. cruzi genetic structure and the clinical forms of the Chagas disease, as well biological characteristics, as virulence, pathogenenicity and susceptibility to drugs, have been extensively investigated by several authors. Although initial studies by Miles et al. (1981) on T. cruzi strains from Venezuela and Brazil suggested the possibility of some correlation between zymodemes and clinical forms, later Apt et al. (1987) and Breniere et al. (1989), did not report any relationship between these parameters. In Argentina, Montamat et al. (1996), observed a correlation between Z12 parasites and high incidence of cardiac lesions in chagasic patients, whereas patients with Z1 parasites were likely to remain asymptomatic for a long time. An extensive study of the biological characteristics of $138 \mathrm{~T}$. cruzi strains and the histopathological profile in experimental animals permitted the division of the strains into three types or biodemes (Andrade \& Magalhães 1997). The authors observed a correspondence between biodemes and zymodemes. A recent study $45 T$. cruzi strains susceptible and naturally resistant to benznidazole and nifurtimox were analyzed for different molecular markers. The heterozygous profile, zymodeme B, contained exclusively susceptible strains, and occurred predominantly in geographic areas where clinical treatment of Chagas disease has been reported as more effective (Murta et al. 1998).

In conclusion, the molecular markers described, (i) reinforced the populacional heterogeneity in $T$. cruzi, (ii) permitted the division of the $T$. cruzi strains into two groups or lineages, one circulating in the sylvatic cycle and another in the domestic cycle of transmission, (iii) evidenced diploidy and 
the genetic exchange in T. cruzi, and (iv) in a certain extent, could be associated with drug susceptibility phenotype in this parasite.

\section{REFERENCES}

Andrade SG, Magalhães JB 1997. Biodemes and zymodemes of Trypanosoma cruzi strains: correlations with clinical data and experimental pathology. Rev Soc Bras Med Trop 30: 27-35.

Apt W, Aguilera X, Arribada A, Gomez L, Miles M, Widmer G 1987. Epidemiology of Chagas disease in Northern Chile: isozyme profiles of Trypanosoma cruzi from domestic and sylvatic transmission cycles and their association with cardiopathy. Am J Trop Med Hyg 37: 302-307.

Avila H, Gonçalves AM, Nehme NS, Morel CM, Simpson L 1990. Schizodeme analysis of Trypanosoma cruzi stocks from South and Central America by analysis of PCR-amplified minicircle variable region sequences. Mol Biochem Parasitol 42: 175-188.

Aymerich S, Goldenberg S 1986. The karyotype of Trypanosoma cruzi Dm28c: comparison with other Trypanosoma cruzi strains and trypanosomatids. Exp Parasitol 69: 107-115.

Bogliolo AR, Chiari E, Silva-Pereira RO, Silva-Pereira AA 1986. A comparative study of enzyme polymorphism in South America. Braz J Med Biol Res 19: 673-683.

Bogliolo AR, Lauria-Pires L, Gibson WC 1996. Polymorphisms in Trypanosoma cruzi: evidences of genetic recombination. Acta Trop 61: 31-40.

Borst P, Van Der Ploeg M, Van Hoek JFM, Tas J, James J 1982. On the DNA content and ploidy of trypanosomes. Mol Biochem Parasitol 6: 13-23.

Brener Z 1973. Biology of Trypanosoma cruzi. Ann Rev Microbiol 27: 347-382.

Breniere SF, Carrasco R, Revollo S, Aparicio G, Desjeux P, Tibayrenc M 1989. Chagas disease in Bolivia: clinical and epidemiological features and zymodeme variability of Trypanosoma cruzi strains isolated from patients. Am J Trop Med Hyg 41: 521-529.

Carneiro M, Chiari E, Gonçalves AM, da Silva Pereira AA, Morel CM, Romanha AJ 1990. Changes in the isoenzyme and kinetoplast DNA patterns of Trypanosoma cruzi strains induced by maintenance in mice. Acta Trop 47: 35-45.

Carrasco HJ, Frame IA, Valente AS, Miles MA 1996. Genetic exchange as a possible source of genomic diversity in sylvatic populations of Trypanosoma cruzi. Am J Trop Med Hyg 54: 418-424.

Chagas C 1909. Nova tripanosomíase humana. Estudos sobre a morfologia e o ciclo evolutivo do Schyzotrypanum cruzi: n.gen., n.sp, agente etiológico de nova morbidade do homem. Mem Inst Oswaldo Cruz 1: 159.

Clark CG, Pung OJ 1994. Host specificity of ribosomal DNA variation in sylvatic Trypanosoma cruzi from North America. Mol Biochem Parasitol 66: 175-179.

Dietrich P, Dussan NP, Floeter-Winter LM, Affonso MH, Camargo EP, Soares MB 1990. Restriction fragment length polymorphisms in the ribosomal gene spacers of Trypanosoma cruzi and Trypanosoma conorhini. Mol Biochem Parasitol 42: 13-20.
Dvorak JA, Hall TE, Crane MS, Engel JC, McDaniel JP, Uriegas R 1982. Trypanosoma cruzi flow cytometric analysis. I. Analysis of total DNA/organism by means of mitramycin-induced fluorescence. J Protozool 24: 430-437.

Finley RW, Dvorak JA 1987. Trypanosoma cruzi: Analysis of the population dynamics of heterogeneous mixtures. J Protozool 34: 409-415.

Gibson AC, Miles MA 1986. The karyotype and ploidy of Trypanosoma cruzi. EMBO J 5: 1299-1305.

Gonçalves A, Nehme N, Morel C 1984. Trypanosomatid characterization by schizodeme analysis, p. 95-109. In CM Morel, Genes and Antigens of Parasites. A laboratory Manual, 2 ed., Fiocruz, Rio de Janeiro.

Henriksson J, Aslund L, Macina RA, Franke de Cazzulo BM, Cazzulo JJ, Frasch AC, Pettersson U 1990. Chromosomal localization of seven cloned antigen genes provides evidence of diploidy and further demonstration of karyotype variability in Trypanosoma cruzi. Mol Biochem Parasitol 42: 213-224.

Henriksson J, Pettersson U, Solari A 1993. Trypanosoma cruzi: correlation between karyotype variability and isoenzyme classification. Exp Parasitol 77: 334-348.

Macedo AM, Pena SDJ 1998. Genetic variability of Trypanosoma cruzi: implications for the pathogenesis of Chagas disease. Parasitol Today 14: 120-124.

Macedo AM, Martins MS, Chiari E, Pena SDJ 1992. DNA fingerprinting of Trypanosoma cruzi: a new tool for characterization of strains and clones. $\mathrm{Mol}$ Biochem Parasitol 55: 147-154.

McDaniel, JP, Dvorak JA 1993. Identification, isolation and characterization of naturally-occurring Trypanosoma cruzi variants. Mol Biochem Parasitol 57: 213-222.

Miles MA, Cedillos RA, Povoa MM, de Souza AA, Prata A, Macedo V 1981. Do radically dissimilar Trypanosoma cruzi strains (zymodemes) cause Venezuelan and Brazilian forms of Chagas disease? Lancet 1: 1338-1340.

Miles MA, Souza AA, Povoa MM, Shaw JJ, Lainson R, Toyé PJ 1978. Isozymic heterogeneity of Trypanosoma cruzi in the first authocthonous patients with Chagas disease in Amazonian Brazil. Nature 272: 819-821.

Miles MA, Toye PJ, Oswald SC, Godfrey DG 1977. The identification by isoenzyme patterns of two distinct strain-groups of Trypanosoma cruzi, circulating independently in a rural area of Brazil. Trans $R$ Soc Trop Med Hyg 71: 217-225.

Montamat E, D’oro G, Gallerano R, Sosa R, Blanco A 1996. Characterization of Trypanosoma cruzi populations by zymodemes: correlation with clinical picture. Am J Trop Med Hyg 55: 625-628.

Morel CM, Chiari E, Camargo EP, Mattei DM, Romanha AJ, Simpson L 1980. Strains and clones of Trypanosoma cruzi can be characterized by pattern of restriction endonuclease products of kinetoplast DNA minicircles. Proc Natl Acad Sci USA 77: 6810-6814.

Murta SMF, Gazzinelli RT, Brener Z, Romanha AJ 1998. Molecular characterization of susceptible and naturally resistant strains of Trypanosoma cruzi to benznidazole and nifurtimox. Mol Biochem Parasitol 
93: 203-214.

Nunes LR, De Carvalho MRC, Buck GA 1997. Trypanosoma cruzi strains partition into two groups based on the structure and function of the spliced leader RNA and rRNA gene promoters. Mol Biochem Parasitol 86: 211-224.

Nusseinzweig V, Goble FC 1966. Further studies on the antigenic constitution of strains of Trypanosoma (Schizotrypanun) cruzi. Exp Parasitol 18: 224-230.

Nusseinzweig V, Kloetzel J, Deane LM 1963. Acquired immunity in mice infected with strains of immunological types A and B of Trypanosoma cruzi. Exp Parasitol 14: 233-239.

Oliveira RP, Broude NE, Macedo AM, Cantor CR, Smith CL, Pena SDJ 1998. Probing the genetic population structure of Trypanosoma cruzi with polymorphic microsatellites. Proc Natl Acad Sci USA 95: 37763780 .

Oliveira RP, Macedo AM, Chiari E, Pena SDJ 1997. Intraespecific genetic variability of parasites revealed by single sequence repeat (SSR)-anchored polymerase chain reaction amplification. Parasitol Today 13: 96-200.

Postan M, McDaniel JP, Dvorak JA 1986. Trypanosoma cruzi: constancy of clone pathogenicity for inbred mice during long-term in vitro maintenance. Trans $R$ Soc Trop Med Hyg 80: 659-662.

Romanha AJ 1982. Heterogeneidade Enzimática em Trypanosoma cruzi, PhD Thesis, UFMG, Belo Horizonte, $110 \mathrm{pp}$.

Souto R, Fernandes O, Macedo AM, Campbell D, Zingales B 1996. DNA markers define two major phylogenetic lineages of Trypanosoma cruzi. Mol Biochem Parasitol 83: 141-152.

Steindel M, Dias Neto E, Menezes CLP, Romanha AJ, Simpson AJG 1993. Random amplified polymorphic DNA analysis of Trypanosoma cruzi strains. Mol Biochem Parasitol 60: 71-80.

Sturm NR, Degrave W, Morel CM, Simpson L 1989. Sensitive detection and schizodeme classification of
Trypanosoma cruzi cells by amplification of kinetoplast minicircle DNA sequence: use in diagnosis of Chagas disease. Mol Biochem Parasitol 33: 205-214.

Tibayrenc M, Ayala FJ 1988. Isozyme variability in Trypanosoma cruzi, the agent of Chagas disease: genetical, taxonomical, and epidemiological significance. Evolution 42: 277-292.

Tibayrenc M, Kjellberg F, Ayala FJ 1990. A clonal theory of parasitic protozoa: the population structures of Entamoeba, Giardia, Leishmania, Naegleria, Plasmodium, Trichomonas and Trypanosoma and their medical and toxonomical consequences. Proc Natl Acad Sci USA 87: 2414-2418.

Tibayrenc M, Neubauer K, Barnabé C, Guerrini F, Skarecky D, Ayala F 1993. Genetic characterization of six parasitic protozoa: Parity between randomprimer DNA typing and multilocus enzyme electrophoresis. Proc Natl Acad Sci USA 90: 1335-1339.

Tibayrenc M, Ward P, Moya A, Ayala FJ 1986. Natural populations of Trypanosoma cruzi, the agent of Chagas disease, have a complex multiclonal structure. Proc Natl Acad Sci USA 83: 1335-1339.

Vago AR, Macedo AM, Adad SJ, Reis DA, CorrêaOliveira R 1996. PCR detection of Trypanosoma cruzi DNA in esophageal tissues of patients with chronic Chagas disease. Lancet 348: 891-892.

Vago AR, Macedo AM, Oliveira RP, Andrade LO, Chiari E, Galvão LMC, Reis DA, Pereira MES, Simpson AJG, Tostes S, Pena SDJ 1996. kDNA signatures of Trypanosoma cruzi strains obtained directly from infected tissues. Am J Pathol 149: 2153-2159.

Zhang Q, Tibayrenc M, Ayala FJ 1988. Linkage disequilibrium in natural populations of Trypanosoma cruzi (flagellate), the agent of Chagas disease. $J$ Protozool 35: 81-85.

Zingales B, Souto RP, Mangia RH, Lisboa CV, Campbel DA, Coura JR, Jansen A, Fernandes O 1998. Molecular epidemiology of American trypanosomiasis in Brazil based on dimorphisms of rRNA and miniexon gene sequences. Int J Parasitol 28: 105-112. 